\title{
Annual variation in diets, feeding locations and foraging behaviour of gannets in the North Sea: flexibility, consistency and constraint
}

\author{
K. C. Hamer ${ }^{1, *}$, E. M. Humphreys ${ }^{1,2}$, S. Garthe ${ }^{3}$, J. Hennicke ${ }^{4}$, G. Peters ${ }^{5}$, \\ D. Grémillet ${ }^{6}$, R. A. Phillips ${ }^{7}$, M. P. Harris ${ }^{8}$, S. Wanless ${ }^{8}$ \\ ${ }^{1}$ Earth Biosphere Institute and Faculty of Biological Sciences, University of Leeds, Leeds LS2 9JT, UK \\ ${ }^{2}$ British Trust for Ornithology Scotland, School of Biological and Environmental Sciences, Stirling University, \\ Stirling FK9 4LA, UK \\ ${ }^{3}$ Centre for Research and Technology Westkuste, University of Kiel, 25761 Büsum, Germany \\ ${ }^{4}$ Institute of Zoology, University of Hamburg, 20146 Hamburg, Germany \\ ${ }^{5}$ Earth \& Ocean Technologies, Krummbogen 32, 24113 Kiel, Germany \\ ${ }^{6}$ Percy FitzPatrick Institute, University of Cape Town, Rondebosch 7701, South Africa \\ ${ }^{7}$ NERC British Antarctic Survey, Madingley Road, Cambridge CB3 0ET, UK \\ ${ }^{8}$ NERC Centre for Ecology and Hydrology, Banchory Research Station, Hill of Brathens, Aberdeenshire AB31 4BY, UK
}

\begin{abstract}
Many seabirds nesting in areas bordering the North Sea have recently experienced large annual variation in breeding success, including reproductive failures in some cases. In contrast, the breeding success of northern gannets Morus bassanus has remained remarkably stable. The present study examines data from the large gannet colony at the Bass Rock (southeast Scotland) across 3 years, to assess the extent to which such stability may reflect both flexibility and consistency in diets and foraging behaviour. Adults exhibited great flexibility both in the species and sizes of prey consumed and in foraging trip durations, ranges and total distances travelled. They also showed a high degree of consistency in bearings of foraging trips and in behaviour at sea; the sinuosity of foraging tracks and average speed of travel was very similar each year and birds in all years spent about half their time at sea in flight. Adults returned to the nest at higher speeds from more distant foraging locations up to ca. $300 \mathrm{~km}$ from the colony, but speeds decreased for the farthest destinations (>ca. $400 \mathrm{~km})$. Moreover, the relationship between trip duration and distances travelled at sea was asymptotic beyond ca. $60 \mathrm{~h}$. These non-linear relationships probably reflected constraints on energy expenditure during flight. As a result, nest attendance was low in years with long average trip durations and chicks were left unattended and vulnerable to attack by conspecifics. These data suggest that while adults have so far been able to maintain high reproductive success in years of low prey availability, they may not be able to do so in future years if providing sufficient food for chicks entails any further increases in trip duration or foraging effort.
\end{abstract}

KEY WORDS: Morus bassanus · Wildlife telemetry · Geolocation · Home range · Optimal foraging

\section{INTRODUCTION}

Foraging behaviour is a major component of the daily routine of many species and during the breeding season forms an essential link between prey availability and predator reproductive success. Flexibility in diet and foraging behaviour may be particularly important when the distribution and abundance of dif- ferent prey species is highly variable. One central issue in this context is how foraging behaviour varies in trips of different duration, especially when parents need to travel long distances to obtain prey (RopertCoudert et al. 2004, Wilson et al. 2005).

Pelagic seabirds routinely travel long distances from the nest, making foraging trips of several hours to several days duration and travelling tens to hundreds 
of kilometres from the breeding site on a single trip (Awkerman et al. 2005, Head \& Gales 2005). Advances in remote-sensing technology have provided increasingly detailed information on the foraging locations and behaviour of pelagic seabirds (Lewis et al. 2004a, 2005, Weimerskirch et al. 2006), but there is still relatively little information on how distances travelled and behaviour during foraging trips vary in relation to trip duration under different environmental conditions (Litzow \& Piatt 2003, Grémillet et al. 2004). Whilst strong evidence exists from a number of species of seabirds that adults are able markedly to increase trip durations in response to low prey availability (e.g. Hamer et al. 1993, Croxall et al. 1999), there is relatively little information to assess how adults adjust their foraging behaviour to compensate for such changes in travel time (Monaghan et al. 1994).

The North Sea is one of the most heavily fished areas in the world and has been affected in recent years by rapid climate-driven changes at multiple trophic levels (Frederiksen et al. 2006). As a result, many species of seabird at colonies bordering the North Sea have recently experienced large annual variation in breeding success, including reproductive failures in some cases (Mavor et al. 2005). In contrast, the breeding success of northern gannets Morus bassanus has remained remarkably stable, varying only between about 0.65 and 0.8 chicks fledged per nest (i.e. 65 to $80 \%$ of the maximum possible) across multiple years at established colonies throughout the region (e.g. see Table 3.6.1 in Mavor et al. 2005). One possible reason for this stability is that gannets appear to have very flexible diets and time/activity budgets during the breeding season. For instance, at one of the largest colonies ( $>40000$ breeding pairs) of gannets in the UK (Bass Rock, southeast Scotland; $56^{\circ} 6^{\prime} \mathrm{N}, 2^{\circ} 36^{\prime} \mathrm{W}$ ) where breeding success is consistently high at around 0.75 chicks fledged per nest (Nelson 2006), the diet in a single year included a wide range of species and sizes of prey while foraging trips lasted from $<2$ to $>84 \mathrm{~h}$ and extended $>500 \mathrm{~km}$ from the nest on some occasions (Hamer et al. 2000). Such flexibility could provide a buffer against the effects of annual variation in prey abundance and distribution and Hamer et al. (2006) found marked annual variation in mean trip durations of chick-rearing adults at the Bass Rock, with particularly long trips in 2002 and short trips in 2003. However, it was not known how much annual variation there was in species and sizes of prey or in foraging locations and movements of adults at sea.

In addition to benefiting from flexibility in diets and foraging behaviour, parents might also benefit in some circumstances from consistency. For instance, they can increase their foraging efficiency by learning the whereabouts of spatially and temporally predictable sources of prey and returning repeatedly to such locations. Gannets at the Bass Rock were shown to display a high degree of such foraging area fidelity in one year (Hamer et al. 2001), but it was not known how this pattern varied between years with different average trip durations.

Gannets feed throughout their foraging trips and Lewis et al. (2004a) found no variation in average feeding rate in relation to trip duration. However, it was not known how the movements of birds at sea or the allocation of time between foraging and nest attendance varied with trip duration. Gannet chicks are normally attended by one parent whilst the other parent is foraging, but prolonged periods of attendance can result in both parents foraging simultaneously, leaving the chick unattended and at risk of attack (Lewis et al. 2004b). It might, thus, be important for birds to return quickly from long trips to relieve their partner at the nest, but no previous data exist to assess the extent to which parents are able to do this. Gannets have an energetically expensive mode of flight that results in high mass-specific energy expenditure during foraging trips (Enstipp et al. 2006). A metabolic ceiling on energy expenditure might, thus, constrain the ability of parents to return quickly from distant foraging sites, but this possibility has not previously been investigated.

This paper provides quantitative information on the diets of gannets at the Bass Rock in different years and uses satellite telemetry to examine annual variation in the foraging locations, distances travelled and at-sea behaviour of chick-rearing adults. We assess how both the consistency in foraging locations exploited by adults and the movements and behaviour of birds during foraging trips differed among 3 years $(1998,2002$ and 2003) with marked differences in average trip duration.

\section{MATERIALS AND METHODS}

Diet. Fieldwork on the Bass Rock (southeast Scotland) took place between 14 June and 28 August each year $(1998,2002$ and 2003). Diet was assessed from regurgitates from adults, and to minimize disturbance most samples were collected from birds at the periphery of the colony, the majority of which were likely to be non-breeders. Comparisons of the frequency of occurrence and sizes of the main prey items in these samples with 20 or more samples known to have come from adults with chicks in the same year showed no evidence of any significant differences in diet between the 2 groups (i.e. these breeders and likely non-breeders) (all $\chi^{2}$ and F-tests, $p>0.05$ ). 
Regurgitates were collected over a period of 2 to $3 \mathrm{~d}$ on 4 to 6 occasions spanning the majority of the chickrearing period before chicks attained peak mass (2 to 3 wk before fledging) each year. Each regurgitate was stored separately in a sealed polythene bag and transported to the laboratory where it was weighed (nearest $1 \mathrm{~g}$ ) and the prey were identified either visually or from sagittal otoliths and vertebrae extracted from the sample (Härkönen 1986, Watt et al. 1997, authors' unpubl. data). Body length of prey was measured to the nearest $1 \mathrm{~cm}$ (1 mm for sandeels Ammodytes marinus) or, where this was not possible, estimated using speciesspecific body length/otolith or vertebra length relationships (Härkönen 1986, Watt et al. 1997, authors' unpubl. data). In addition, sandeels were aged by the absence (0-group) or presence (older age groups) of annual growth rings in the otoliths (Anonymous 1995). Dietary data are presented in terms of both frequency of occurrence and the proportions of the total biomass comprised of the different species each year.

Satellite telemetry. One chick-rearing adult from each of 53 nests with hatching dates \pm 2 wk from the annual mode ( $\mathrm{n}=17$ birds in 1998, 14 in 2002, 22 in 2003) was captured at the nest using a roach pole with a brass noose. In 1998 and 2002, a platform terminal transmitter (PTT; Microwave Telemetry) weighing $30 \mathrm{~g}$ (ca. $1 \%$ of adult mass) and with a duty cycle of continuous transmission was then attached with self-amalgamating tape (RS Components) to the underside of the 4 central tail feathers of each bird, close to the base of the tail with the aerial pointing upwards through the feathers. This arrangement minimized drag during flight and prevented tags being displaced during plunge diving. In 2003, a PTT was attached to 9 birds as above and a GPS logger (Earth \& Ocean Technologies) weighing $70 \mathrm{~g}(<3 \%$ of adult mass $)$ was attached to the feathers on the back of 13 birds using Tesa tape, such that the wings of the bird protected the device during plunge diving. Attachment of all tags took $<15 \mathrm{~min}$, and after release every bird returned to the nest almost immediately.

After release, birds were tracked for 5 to $21 \mathrm{~d}$ each $($ mean $=12 \mathrm{~d})$ for birds wearing PTTs and for 1 to $4 \mathrm{~d}$ each (mean $=3 \mathrm{~d}$ ) for birds wearing GPS loggers, during a period of 2 mo (24 June to 25 August) excluding late chick rearing, after which time the bird was recaptured and the tag removed. A recent review of effects of satellite transmitters indicated negligible adverse effects for tags weighing up to $3 \%$ of adult body mass (Phillips et al. 2003) and in our study, PTTs had no discernible effects on trip durations or body masses of birds in comparison with untagged controls (Hamer et al. 2000). In addition, there was no difference between birds carrying PTTs and those carrying GPS loggers in trip durations (mean $\pm \mathrm{SD}, 27.3 \pm 10.2 \mathrm{~h}, \mathrm{n}=43$ and
$21.5 \pm 6.7 \mathrm{~h}, \mathrm{n}=15$, respectively, $t_{56}=2.0, \mathrm{p}=0.1$ ) or maximum distances travelled from the colony (see below for method of calculation; mean $=105.7 \pm 102.4$ $\mathrm{km}, \mathrm{n}=43$ and $155.2 \mathrm{~km} \pm 65.3, \mathrm{n}=15$, respectively; $t_{56}$ $=0.7, \mathrm{p}=0.5$ ) in 2003 .

Data provided by PTTs were processed using the Advanced Research and Global Observation Satellite (ARGOS) facility in France (Centre National d'Etudes Spatiales [CNES]). Following Hamer et al. (2000), we used only data of Class A or better to examine foraging locations at sea, giving us a maximum SD on each location of $7 \mathrm{~km}$, which was small in comparison with distances travelled by birds (see below). GPS loggers provided data at intervals of $3 \mathrm{~min}$, which were then sampled at 30 min intervals to maintain comparability with the PTT data. Trials indicated that the accuracy of this system was within $20 \mathrm{~m}$ for $90 \%$ of all fixes. Locations of birds at sea were examined in Arc-View GIS and the scale of movements each year was compared using fixed kernel density (FKD) estimates (Beisiegel \& Mantovani 2006). As described by others (e.g. Iversen \& Esler 2006) we considered the 95 and $50 \%$ FKD estimates to represent the area of active use and the core area of foraging activity, respectively.

To examine individual foraging trips in more detail, we used trips with locations at average intervals of $\leq 3 \mathrm{~h}$ to assess the routes taken by birds. We used the farthest recorded location from the colony during each of these trips to provide information on trip destinations and we calculated trip durations from the time of the first location after the bird had left the colony until the time of the first location after it had returned, as described by Hamer et al. (2000). We also calculated total distance travelled as the sum of distances between consecutive locations at sea. To assess whether there were constraints on foraging ranges we examined both linear and asymptotic relationships between trip durations and distances travelled at sea. Using an information-theoretic approach to model selection, we calculated Akaike's Information Criterion (AIC; Burnham \& Anderson 1998) for each model and used F-tests to determine whether differences between models were significant. We then calculated the proportion of time that each bird spent foraging as:

Mean trip duration

Mean trip duration + Mean time at colony between trips

This made the most efficient use of the data whilst ensuring that periods of foraging and attendance at the nest were equally represented. To reduce sampling error, this analysis was restricted to birds with 3 or more consecutive foraging trips and hence 2 or more consecutive periods at the nest between trips. 
To examine whether or not there was consistent variation in the foraging locations of individual birds, we used data recorded at average intervals of $3 \mathrm{~h}$ or less over a minimum of 3 consecutive foraging trips. Following Hamer et al. (2001), we calculated mean bearings of destinations from the colony for each bird and used angular deviation to measure how consistent birds were in their bearings on successive trips (angular deviation is equivalent to SD in linear data and ranges from a minimum of zero to a maximum of $81.0^{\circ}$ ).

To examine movements over shorter intervals within the total foraging ranges of birds, we estimated travel speeds during short sections of each trip as the distance between consecutive pairs of locations divided by the time elapsed between them. In view of the maximum SDs on locations (see above), very short intervals between locations could produce erroneous estimates of speed. To avoid this problem, we used only pairs of locations at sea separated by at least $1 \mathrm{~h}$ for PTTs or by 30 min for GPS loggers.

In many cases we recorded more than 1 trip per bird. To examine annual and individual variation in foraging behaviour and to take account of potential pseudoreplication of data, we used generalized linear models (GLMs) with year included as a fixed effect, and bird identity included as a random effect nested within year.

\section{RESULTS}

\section{Diet}

We obtained a total of 472 regurgitates (biomass = $51.1 \mathrm{~kg}$ ), all of which either contained 1 species of prey or 2 species occupying different portions of the sample and so probably ingested separately. The diet included a wide range of species, but the main prey in terms of frequency of occurrence and proportion of biomass were sandeels (mainly 0-group), mackerel Scomber scombrus, herring Clupea harengus, sprat Sprattus sprattus and Gadidae (Table 1). There was marked variation in diet between years $\left(\chi^{2}\right.$-test of frequency data with 0-group and older sandeels combined; $\chi_{10}^{2}=$ 67.4, $\mathrm{p}<0.0001$ ). In particular, sandeels were 2 to 3 times more abundant in the diet in 2002 and 2003 than in 1998, whereas the abundance of herring and sprat in 2002 was about one-quarter to one-third of that in other years. Estimates of the sizes of prey taken indicated that these also varied markedly in all 3 years, with a total range from $5 \mathrm{~cm}$ (0-group sandeels) to $40 \mathrm{~cm}$ (mackerel and haddock Melanogrammus aeglefinus; Table 2). However, there was little difference between years in the range of prey sizes (5 to $37 \mathrm{~cm}$ in 1998,5 to $40 \mathrm{~cm}$ in 1002,5 to $38 \mathrm{~cm}$ in 2003 ; Table 2).

\section{Foraging trip durations and time spent foraging}

We obtained 5716 high-quality locations at sea (SD \pm $7 \mathrm{~km}$; see 'Materials and methods') during foraging trips made by 53 birds (17 birds in 1998, 14 birds in 2002, 22 birds in 2003 of which 13 were carrying GPSloggers). From these, there were 170 foraging trips from 48 birds with locations at average intervals of $\leq 3 \mathrm{~h}$, allowing reasonably accurate assessment of trip durations and routes taken by adults. Trips lasted up to $75 \mathrm{~h}$ in 1998, $93 \mathrm{~h}$ in 2002 and $54 \mathrm{~h}$ in 2003. Mean trip duration in 2002 was about $60 \%$ longer than in 2003 and $30 \%$ longer than in 1998 (Table 3; GLM; $F_{2,122}=$ 16.6, $\mathrm{p}<0.001)$. There were, however, no significant differences in trip durations of individual birds within each year $\left(F_{45,122}=0.8, \mathrm{p}=0.8\right)$.

Adults each spent slightly more than half of their time at sea on average (Table 3), so that chicks were sometimes left unattended in all 3 years (authors' pers. obs. at colony). Coinciding with the shortest trip durations in 2003, the proportion of time that each 
Table 2. Morus bassanus. Lengths (cm) of fish eaten at Bass Rock in the 3 years studied

\begin{tabular}{|c|c|c|c|c|c|c|c|c|c|c|c|c|}
\hline \multirow[t]{2}{*}{ Species } & \multicolumn{4}{|c|}{$\longrightarrow 1998 \longrightarrow$} & \multicolumn{4}{|c|}{$2002-$} & \multicolumn{4}{|c|}{2003} \\
\hline & $\mathrm{n}$ & Mean & $\mathrm{SD}$ & Range & $\mathrm{n}$ & Mean & $\mathrm{SD}$ & Range & $\mathrm{n}$ & Mean & $\mathrm{SD}$ & Range \\
\hline \multicolumn{13}{|l|}{ Lesser sandeel $^{\mathrm{a}}$} \\
\hline 0-group & 2016 & 7.8 & 0.90 & $5-10$ & 7477 & 8.2 & 0.86 & $5-9$ & 5177 & 7.7 & 0.72 & $5-10$ \\
\hline Older & 432 & 11.6 & 1.45 & $9-17$ & 2 & 11.0 & 0.98 & $11-11$ & 77 & 9.7 & 0.53 & $9-11$ \\
\hline Sprat $^{a}$ & 375 & 9.8 & 1.55 & $5-15$ & 21 & 8.8 & 3.07 & $6-15$ & 35 & 10.6 & 1.60 & $8-16$ \\
\hline Herring & 53 & 20.7 & 4.00 & $10-30$ & 21 & 24.4 & 6.87 & $10-31$ & 41 & 17.6 & 7.17 & $8-25$ \\
\hline Mackerel & 42 & 24.9 & 4.41 & $15-33$ & 28 & 32.0 & 4.39 & $23-40$ & 18 & 30.5 & 3.78 & $21-36$ \\
\hline Haddock & 15 & 29.1 & 6.24 & $18-37$ & 5 & 35.6 & 3.15 & $31-40$ & 7 & 32.7 & 5.16 & $22-38$ \\
\hline Whiting & 12 & 26.9 & 5.33 & $18-34$ & 19 & 20.9 & 5.19 & $12-32$ & 2 & 27.8 & 3.05 & $24-30$ \\
\hline Cod & 4 & 26.2 & 6.58 & $20-30$ & 2 & 32.3 & 9.23 & $26-39$ & - & - & - & - \\
\hline Grey gurnard & 3 & 13.0 & 1.73 & $11-16$ & - & - & - & - & - & - & - & - \\
\hline Salmon & 2 & 26.0 & 0 & $26-26$ & - & - & - & - & - & - & - & - \\
\hline Trout & 1 & 34.0 & - & - & - & - & - & - & - & - & - & - \\
\hline Greater forkbeard & 1 & 25.0 & - & - & - & - & - & - & - & - & - & - \\
\hline Dragonet & - & - & - & - & 1 & 22.9 & - & - & - & - & - & - \\
\hline Greater sandeel & - & - & - & - & - & - & - & - & 3 & 16.2 & 0.66 & $16-17$ \\
\hline Garfish & - & - & - & - & - & - & - & - & 1 & 36.0 & - & - \\
\hline Scad & - & - & - & - & - & - & - & - & 1 & 38.3 & - & - \\
\hline
\end{tabular}

Table 3. Morus bassanus. Characteristics of foraging trips made by adults rearing chicks at Bass Rock in the 3 years studied. Based on 70 trips (21 to north of colony; 49 to south) from 14 birds in 1998, 42 trips (24 to north; 18 to south) from 13 birds in 2002, 58 trips (36 to north; 22 to south) from 21 birds in 2003. FKD: fixed kernel density estimate

\begin{tabular}{|c|c|c|c|c|c|c|}
\hline & \multicolumn{2}{|c|}{$-1998-$} & \multicolumn{2}{|c|}{$-2002-$} & \multicolumn{2}{|c|}{$-2003-$} \\
\hline & Mean & $\mathrm{SD}$ & Mean & $\mathrm{SD}$ & Mean & $\mathrm{SD}$ \\
\hline $\begin{array}{l}\text { Proportion of } \\
\text { time foraging }(\%)^{\mathrm{a}}\end{array}$ & 60.3 & 5.5 & 57.4 & 4.0 & 52.5 & 7.5 \\
\hline Trip duration (h) & 31.5 & 13.0 & 40.0 & 17.6 & 25.9 & 9.6 \\
\hline $\begin{array}{l}95 \% \text { FKD }\left(\mathrm{km}^{2}\right) \\
50 \% \text { FKD }\left(\mathrm{km}^{2}\right)\end{array}$ & \multicolumn{2}{|c|}{$\begin{array}{l}96290 \\
10822\end{array}$} & \multicolumn{2}{|c|}{$\begin{array}{r}211120 \\
30555\end{array}$} & \multicolumn{2}{|c|}{$\begin{array}{r}45890 \\
4202\end{array}$} \\
\hline $\begin{array}{l}\text { Max. distance }(\mathrm{km}) \\
\text { Total distance }(\mathrm{km})\end{array}$ & $\begin{array}{l}224.3 \\
588.2\end{array}$ & $\begin{array}{r}96.8 \\
245.5\end{array}$ & $\begin{array}{l}319.7 \\
786.0\end{array}$ & $\begin{array}{l}132.9 \\
344.3\end{array}$ & $\begin{array}{l}170.5 \\
417.6\end{array}$ & $\begin{array}{r}94.2 \\
231.3\end{array}$ \\
\hline $\begin{array}{l}\text { Trips to north of colon } \\
\text { Max. distance }(\mathrm{km}) \\
\text { Total distance }(\mathrm{km})\end{array}$ & $\begin{array}{l}203.0 \\
546.8\end{array}$ & $\begin{array}{r}85.2 \\
216.1\end{array}$ & $\begin{array}{l}363.7 \\
902.9\end{array}$ & $\begin{array}{c}93.9 \\
331.0\end{array}$ & $\begin{array}{l}181.7 \\
444.4\end{array}$ & $\begin{array}{r}93.9 \\
230.0\end{array}$ \\
\hline $\begin{array}{l}\text { Trips to south of colon } \\
\text { Max. distance }(\mathrm{km}) \\
\text { Total distance }(\mathrm{km})\end{array}$ & $\begin{array}{l}233.4 \\
606.0\end{array}$ & $\begin{array}{l}100.8 \\
257.0\end{array}$ & $\begin{array}{l}261.0 \\
630.2\end{array}$ & $\begin{array}{l}112.0 \\
304.5\end{array}$ & $\begin{array}{l}152.2 \\
373.7\end{array}$ & $\begin{array}{r}93.8 \\
231.8\end{array}$ \\
\hline $\begin{array}{l}\operatorname{Speed}^{\mathrm{b}}\left(\mathrm{km} \mathrm{h}^{-1}\right) \\
\text { Speed }^{\mathrm{c}}\left(\mathrm{km} \mathrm{h}^{-1}\right.\end{array}$ & $\begin{array}{l}14.4 \\
18.9\end{array}$ & $\begin{array}{l}3.2 \\
3.8\end{array}$ & $\begin{array}{l}16.3 \\
19.5\end{array}$ & $\begin{array}{l}3.7 \\
4.3\end{array}$ & $\begin{array}{l}14.1 \\
18.3\end{array}$ & $\begin{array}{l}3.9 \\
4.2\end{array}$ \\
\hline
\end{tabular}

adult spent foraging was also lowest in 2003 (Table 3), although there was no significant difference between 1998 and 2002 in this respect (1-way ANOVA using arcsine-transformed data with a single value for each bird, followed by post-hoc Tukey tests; $F_{2,22}=4.0$, $\mathrm{p}=0.03)$.

\section{Locations of adults at sea}

Locations of birds during trips covered a wide area of the North Sea (>200000 km²; Fig. 1), extending as far as Bergen/Viking Bank (southwest Norway) in the north and the Frisian Islands (northwest Netherlands) in the south. Fixed kernel density estimates indicated that the area used for foraging (95\% FKD) was largest in 2002; 2.2 times larger than that in 1998 and 4.6 times larger than that in 2003 (Table 3), with the foraging areas in 1998 and 2003 almost entirely nested within the larger area used in 2002 (Fig. 2). The core foraging area (50\% FKD) was also largest in 2002; 2.8 times larger than that in 1998 and 7.3 times larger than that in 2003 (Table 3). Despite these differences between years in distances travelled by birds, the core foraging area was a similar proportion of the total area used for foraging each year $(11.2 \%$ in $1998,14.5 \%$ in $2002,9.2 \%$ in 2003; calculated from data in Table 3).

Individual foraging trips showed approximately 10 -fold variation each year in terms of both total distance travelled (146-1291 km in 1998, $156-1547 \mathrm{~km}$ in 2002, 68-1175 km in 2003) and maximum distance attained from the colony (39-545 km, $67-590 \mathrm{~km}$ and $24-430 \mathrm{~km}$, respectively). Destinations of trips had a highly non-random distribution (propor- 


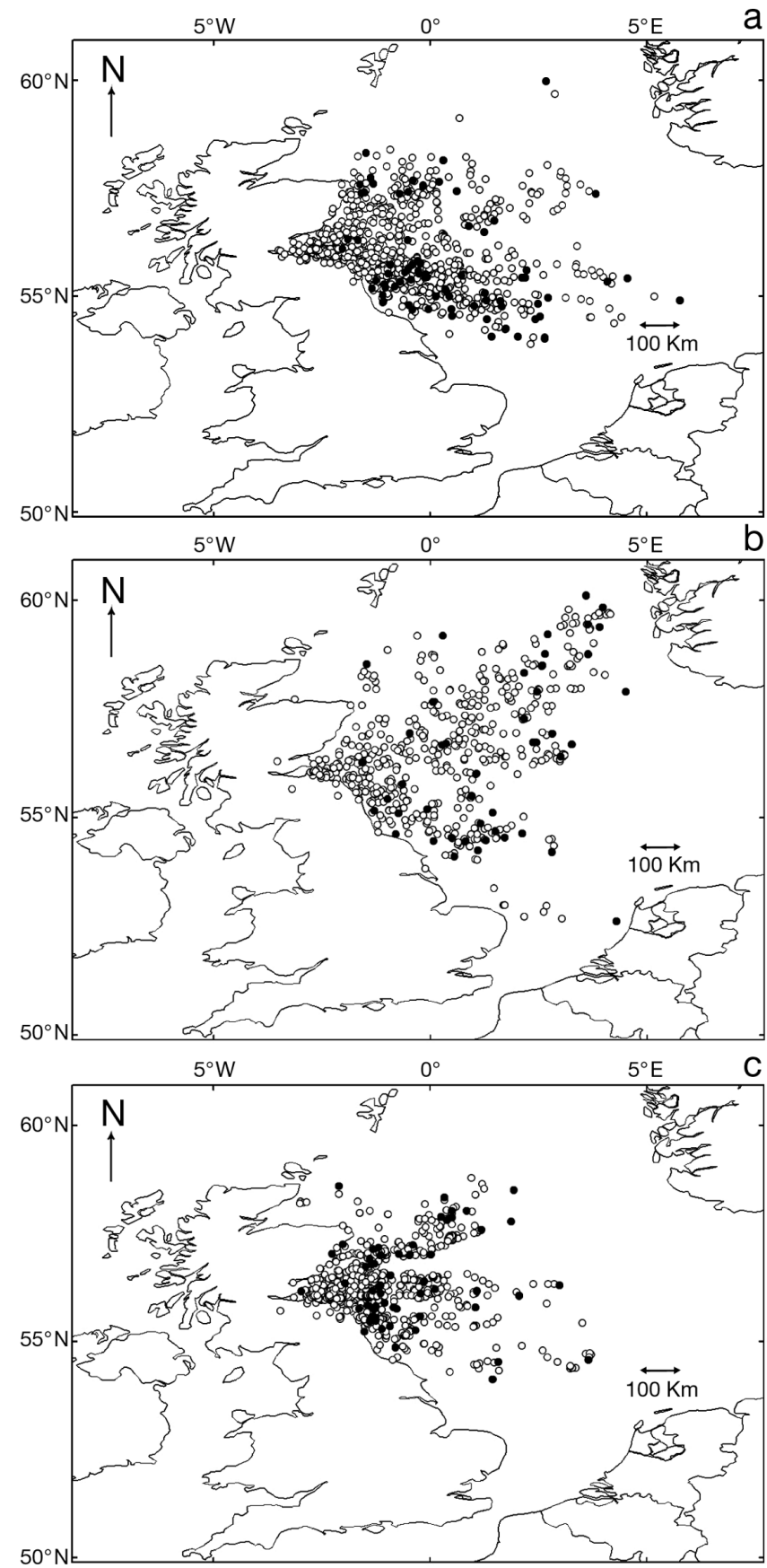

Fig. 1. Morus bassanus. Foraging ranges and destinations of foraging trips from Bass Rock, southeast Scotland in (a) 1998, (b) 2002, (c) 2003. O: locations of adults at sea; $\bullet$ : destinations of foraging trips

tion of trips with farthest locations in each of 5 consecutive sectors, each subtending an angle of $30^{\circ}$ at the colony; $\chi_{4}^{2}=17.6, p=0.001$ ) with more trips northeast and southeast and fewer trips east of the colony than would be expected by chance (Fig. 1). Both for trips north of the colony (bearing $\leq 90^{\circ}$ ) and for trips south of the colony (bearing $>90^{\circ}$ ), individual birds in all
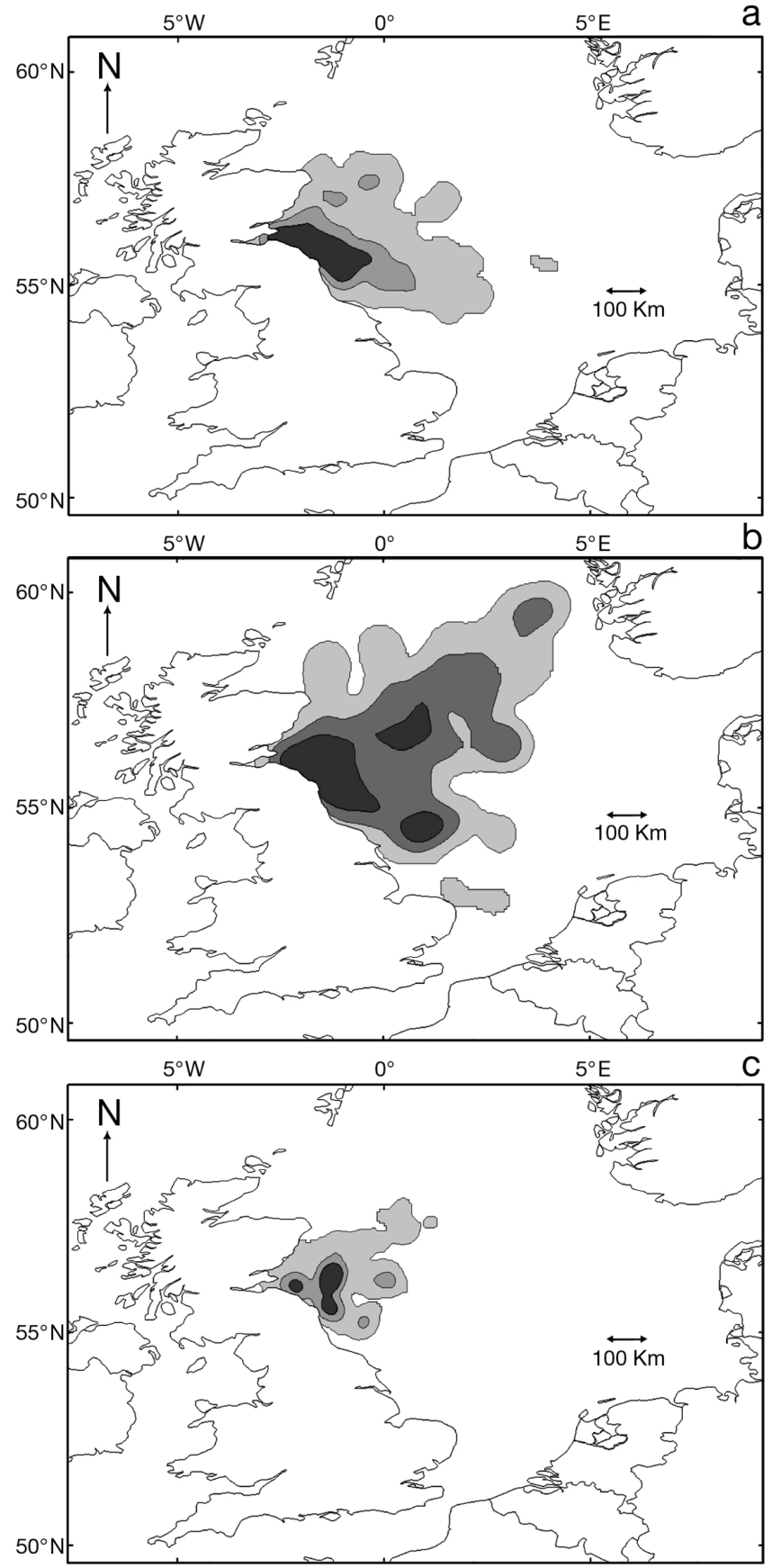

Fig. 2. Morus bassanus. Kernels encompassing $50 \%$ (dark grey), $75 \%$ (medium grey) and $95 \%$ (light grey) of foraging locations from the Bass Rock in (a) 1998, (b) 2002 and (c) 2003

3 years tended to make successive trips on similar bearings with little angular deviation from one trip to the next (Table 4). Accordingly, bearings of destinations varied significantly among birds both for trips to the north of the colony (GLM with bird identity nested within year; $\left.F_{30,48}=3.0, \mathrm{p}<0.001\right)$ and for trips to the south of the colony $\left(F_{24,62}=5.5, \mathrm{p}<0.001\right)$. There was, 
Table 4. Morus bassanus. Mean bearings and angular deviations for foraging trips from Bass Rock. $n$ : number of foraging trips in each direction for each bird

\begin{tabular}{|c|c|c|c|c|c|c|c|}
\hline & \multirow[t]{2}{*}{ Bird } & \multirow[t]{2}{*}{$\mathrm{n}$} & \multicolumn{2}{|c|}{ Trips SE } & \multirow{2}{*}{$\mathrm{n}$} & \multicolumn{2}{|c|}{ Trips NE } \\
\hline & & & $\begin{array}{c}\text { Mean } \\
\text { bearing }\left({ }^{\circ}\right)\end{array}$ & $\begin{array}{l}\text { Angular } \\
\text { deviation }\end{array}$ & & $\begin{array}{c}\text { Mean } \\
\text { bearing }\left({ }^{\circ}\right)\end{array}$ & $\begin{array}{l}\text { Angular } \\
\text { deviation }\end{array}$ \\
\hline \multirow[t]{10}{*}{1998} & 1 & 5 & 137.4 & 5.7 & 3 & 45.6 & 7.8 \\
\hline & 2 & 4 & 130.2 & 5.8 & 3 & 74.6 & 0.2 \\
\hline & 3 & 4 & 118.2 & 5.8 & 2 & 21.8 & 1.0 \\
\hline & 4 & 6 & 111.7 & 8.3 & 1 & 38.1 & - \\
\hline & 5 & 1 & 119.4 & - & 7 & 37.8 & 12.6 \\
\hline & 6 & 1 & 100.9 & - & 3 & 50.9 & 24.3 \\
\hline & 7 & 8 & 110.5 & 7.6 & 0 & - & - \\
\hline & 8 & 8 & 124.5 & 9.8 & 0 & - & - \\
\hline & 9 & 6 & 122.3 & 5.1 & 0 & - & - \\
\hline & 10 & 6 & 111.2 & 7.4 & 0 & - & - \\
\hline \multirow[t]{8}{*}{2002} & 11 & 3 & 132.0 & 3.2 & 6 & 61.9 & 22.8 \\
\hline & 12 & 4 & 128.4 & 7.1 & 0 & - & - \\
\hline & 13 & 3 & 103.4 & 9.3 & 0 & - & - \\
\hline & 14 & 3 & 133.2 & 5.1 & 0 & - & - \\
\hline & 15 & 3 & 117.0 & 8.1 & 0 & - & - \\
\hline & 16 & 0 & - & - & 6 & 53.1 & 8.2 \\
\hline & 17 & 0 & - & - & 5 & 65.6 & 11.2 \\
\hline & 18 & 0 & - & - & 3 & 42.0 & 3.1 \\
\hline \multirow[t]{7}{*}{2003} & 19 & 2 & 139.7 & 3.5 & 4 & 42.6 & 28.3 \\
\hline & 20 & 9 & 121.4 & 11.6 & 1 & 59.4 & - \\
\hline & 21 & 2 & 101.9 & 4.1 & 1 & 86.2 & - \\
\hline & 22 & 6 & 121.6 & 8.1 & 0 & - & - \\
\hline & 23 & 0 & - & - & 8 & 41.3 & 6.4 \\
\hline & 24 & 0 & - & - & 5 & 35.5 & 3.4 \\
\hline & 25 & 0 & - & - & 3 & 15.8 & 12.9 \\
\hline
\end{tabular}

however, no difference between years in bearings of trips in either case $\left(F_{2,48}=1.9, \mathrm{p}=0.2\right.$ and $F_{2,62}=2.0$, $\mathrm{p}=0.2$, respectively).

Despite the large variation in distances travelled during foraging trips each year, there was a highly significant difference between years in distances to destinations of trips (Table 3; GLM including direction [to north or south of colony] as a fixed effect; $\left.F_{2,119}=14.5, \mathrm{p}<0.001\right)$. Trips were longest in 2002 and shortest in 2003, with distances in 1998 intermediate. Total distances travelled during trips followed a similar pattern (Table $3 ; F_{2,119}=13.8, \mathrm{p}<0.001$ ). Neither total distance travelled nor maximum distance from the colony differed significantly among birds within each year $\left(F_{45,119}=0.9, \mathrm{p}=0.7\right.$ and $F_{45,119}$ $=1.1, \mathrm{p}=0.3$, respectively) or between trips to the north and south of the colony $\left(F_{1,119}=0.04, \mathrm{p}=0.8\right.$ and $F_{1,119}=0.04, \mathrm{p}=0.8$, respectively; there were no significant interactions between direction and year). Total distance travelled was on average 2.47 (SE \pm 0.03) times the maximum distance from the colony and there was no difference in the slope of this relationship between years (GLM excluding intercept; $F_{2,119}=2.5, \mathrm{p}=0.1$ ) or between birds within each year $\left(F_{45,119}=1.3, \mathrm{p}=0.1\right)$.

\section{Average speeds of travel over complete trips}

Despite the large differences between years in trip durations and distances travelled, there was a highly significant relationship between trip duration and both maximum distance (Fig. 3) from the colony $\left(F_{1,169}=1691.0 .4, \mathrm{p}<0.001, \mathrm{R}^{2}=0.91\right)$ and total distance travelled (Fig. $4 ; F_{1,169}=1944.5, \mathrm{p}<0.001, \mathrm{R}^{2}=$ 0.92). The most appropriate model, as determined from AIC, was a linear relationship up to an asymptote of $440 \mathrm{~km}$ for trips longer than $62 \mathrm{~h}$ in the case of

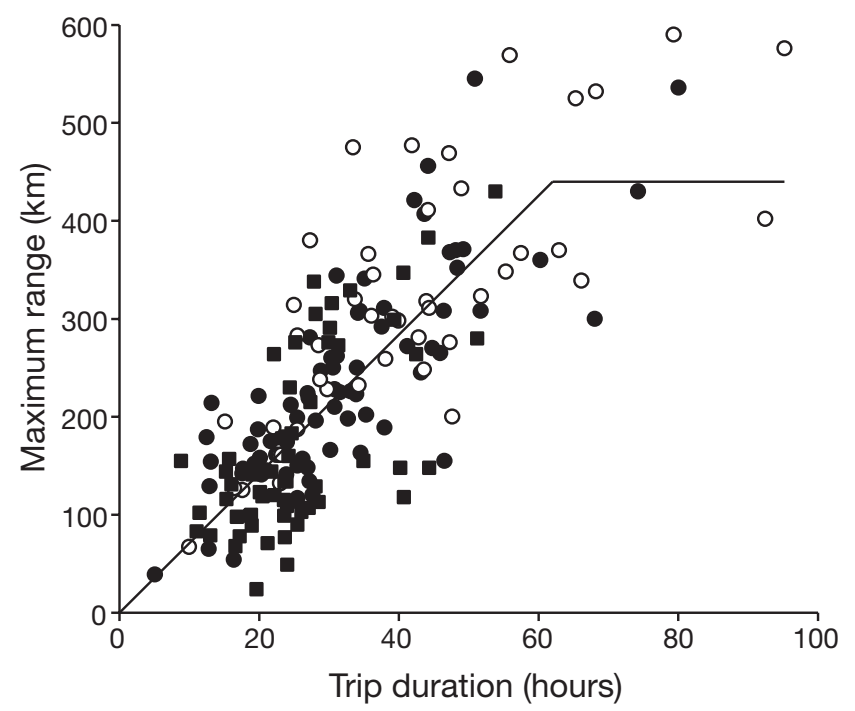

Fig. 3. Morus bassanus. Relationship between distance to destination and foraging trip duration in 1998 (๑), 2002 (O) and 2003

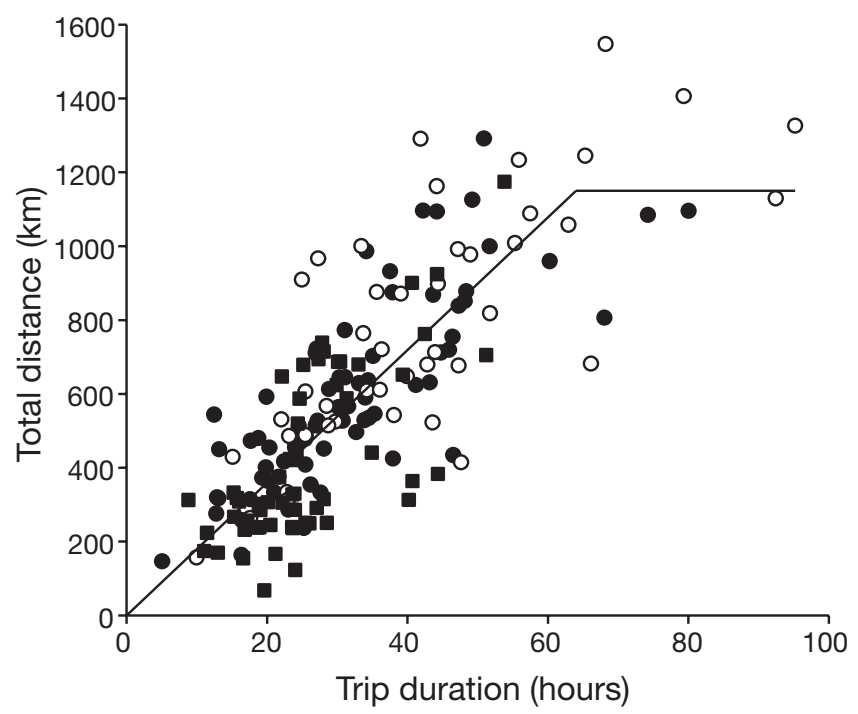

Fig. 4. Morus bassanus. Relationship between total distance travelled and foraging trip duration in 1998 (๑), 2002 (O) and $2003(\square)$ 
maximum distance and $1150 \mathrm{~km}$ for trips longer than $64 \mathrm{~h}$ in the case of total distance travelled (Fig. 4; $F$-test for improvement over linear model $F_{1,168}=9.3$, $\mathrm{p}<0.01$ and $F_{1,168}=7.2, \mathrm{p}<0.01$ respectively). For trips below these asymptotes, linear relationships were according to the following equations:

$$
\begin{aligned}
& \text { Maximum distance }(\mathrm{km})= \\
& 7.4(\mathrm{SE} \pm 0.18) \times \text { trip duration }(\mathrm{h}) \\
& \text { Total distance }(\mathrm{km})= \\
& 18.5(\mathrm{SE} \pm 0.41) \times \text { trip duration }(\mathrm{h})
\end{aligned}
$$

Average speed during these trips was, thus, estimated as $14.8(\mathrm{SE} \pm 0.4) \mathrm{km} \mathrm{h}^{-1}$ (twice the slope of Eq. 2) using maximum distance from the colony and as 18.5 ( $\mathrm{SE} \pm$ 0.4) $\mathrm{km} \mathrm{h}^{-1}$ (the slope of Eq. 3) using total distance travelled. GLM indicated no difference between years in the slopes of these relationships $\left(F_{2,112}=1.4, \mathrm{p}=0.3\right.$ and $F_{2,112}=0.6, \mathrm{p}=0.5$, respectively) and this was confirmed by comparison among years of the mean travel speeds for individual birds (Table 3; 1-way ANOVA with a single value for each bird; from maximum distance from the colony, $F_{2,44}=1.5, \mathrm{p}=0.2$; from total distance travelled, $F_{2,44}=1.0, \mathrm{p}=0.4$ ). Average travel speeds on trips longer than $60 \mathrm{~h}$ were significantly slower (from maximum distance from the colony, mean $=12.2(\mathrm{SE} \pm 0.51) \mathrm{km} \mathrm{h}^{-1}, t_{168}=5.7, \mathrm{p}<0.001$; from total distance travelled, mean $=15.5(\mathrm{SE} \pm 1.9) \mathrm{km} \mathrm{h}^{-1}, t_{168}=$ 2.3, $\mathrm{p}=0.02$ ).

\section{Variation in travel speeds during trips}

Speeds of travel over short intervals within trips were calculated using consecutive pairs of locations with $\geq 30$ min between them (see 'Materials and methods'). Gannets do not travel at night (Hamer et al. 2000) and in this study, speed of travel during daylight hours was highly dependent on the interval between locations $\left(\mathrm{GLM} ; F_{1,1162}=72.5, \mathrm{p}<0.001\right)$, according to the following equation:

Travel speed $\left(\mathrm{km} \mathrm{h}^{-1}\right)=31.8(\mathrm{SE} \pm 1.1)$
$-3.2(\mathrm{SE}+0.4)$ interval $(\mathrm{h})$

There was no difference between years in either the slope or the elevation of this relationship $\left(F_{2,1162}=0.7\right.$, $\mathrm{p}=0.5$ and $F_{2,1162}=2.5, \mathrm{p}=0.1$, respectively), but there was significant variation among birds within each year $\left(F_{45,1162}=2.2, \mathrm{p}<0.001\right)$. Travel speed over the shortest intervals (32 $\mathrm{km} \mathrm{h}^{-1}$, from Eq. 4) was about half average flight speed (55 $\mathrm{km} \mathrm{h}^{-1}$; Grémillet et al. 2004).

Birds travelled out from the colony and returned at similar speeds (mean $\pm \mathrm{SD} ; 20.1 \pm 13.8 \mathrm{~km} \mathrm{~h}^{-1}, \mathrm{n}=170$ and $17.0 \pm 11.6 \mathrm{~km} \mathrm{~h}^{-1}, \mathrm{n}=170$, respectively). Travel speed during the outward leg of the journey was independent of distance to destination, but speed during

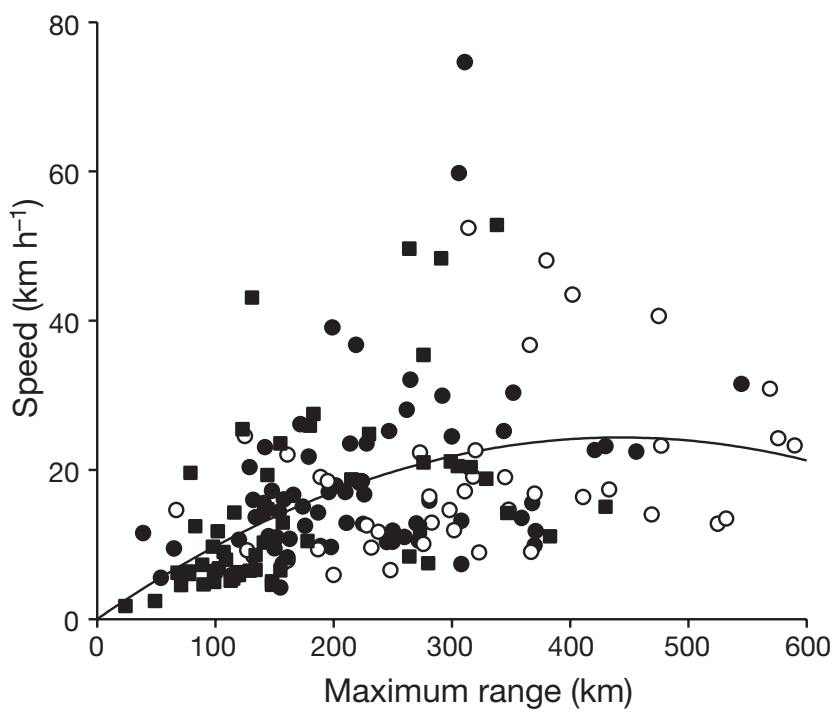

Fig. 5. Morus bassanus. Relationship between distance to destination and return travel speed in 1998 (0), 2002 (O) and 2003(

the return leg was significantly related to distance (Fig. 5; stepwise multiple regression; $F_{2,168}=248.8$, $\mathrm{p}<0.001, \mathrm{R}^{2}=0.75$ ) according to the following quadratic equation:

Travel speed $\left(\mathrm{km} \mathrm{h}^{-1}\right)=0.11(\mathrm{SE} \pm 0.01)$ distance

$-1.24 \times 10^{-4}\left(\mathrm{SE} \pm 0.01 \times 10^{-4}\right)$ distance $^{2}$

A GLM confirmed that return travel speed was significantly related to both distance $\left(F_{1,120}=12.1, \mathrm{p}=0.001\right)$ and distance ${ }^{2}\left(F_{1,120}=5.5, \mathrm{p}=0.02\right)$ with no difference in this relationship between years $\left(F_{2,120}=1.5, \mathrm{p}=0.2\right)$ or between birds within each year $\left(F_{45,119}=0.8, \mathrm{p}=0.7\right)$. Calculation of AIC further indicated that Eq. (5) described the data significantly better than a simple linear relationship ( $F$-test for improvement in $\mathrm{AIC}_{i} F_{1,169}=27.4$, $\mathrm{p}<0.01$ ). Birds returned at a faster rate from more distant locations up to $300-400 \mathrm{~km}$ from the nest, beyond which there was a significant reduction in speed (Fig. 5).

\section{DISCUSSION}

\section{Flexibility in diet and foraging ranges}

Many seabirds along North Sea coasts as far north as Shetland experienced very low reproductive success in 1998, which was linked to low availability of sandeels in late June and July (Thompson et al. 1999). In addition, several species at colonies in southeast Scotland and northeast England experienced below average success in 2002 whilst, with the exception of colonies in Shetland, breeding success was generally high in 2003 (Mavor et al. 2004). In contrast, gannets experienced 
very little variation in reproductive success over this period, and this stability largely reflects the high degree of flexibility that they exhibited in their diets and foraging ranges. Not only were adults able to exploit a wide range of species and sizes of prey, obtained using several distinct capture techniques (vertical plunge-diving, underwater pursuit, scooping from the surface and scavenging discards from fishing vessels; Garthe et al. 2000, Lewis et al. 2002), but also the proportions of the different species caught varied markedly between years, with only 0-group sandeels being an important component $(>25 \%)$ of the diet every year (Table 1 ). In addition, adults were not only able to exploit prey resources over a very large foraging area (Figs. 1 \& 2), but also exhibited marked annual variation in trip durations, foraging ranges and total distances travelled at sea (Table 3). Trips were longest in 2002, when the abundance of 0-group sandeels over the majority of the North Sea was an order of magnitude lower than in the other 2 years studied and only $13 \%$ of the long-term (1983 to 2005) average (Table 1.4.24.4. in ICES 2005).

In all years studied, gannets at the Bass Rock made more trips to the northeast and southeast and fewer trips due east of the colony than would be expected by chance (Fig. 1). There was no difference in distances travelled by birds in these directions but the proportion of trips to the north of the colony increased from $30 \%$ in 1998 to $62 \%$ in 2003 (Table 3). This change may have reflected a decrease in the quality of prey at lower latitudes in recent years in terms of both size and lipid content (Wanless et al. 2004, 2005), but further data are needed to examine latitudinal variation in the sizes and caloric densities of prey species within the North Sea.

\section{Consistency of foraging behaviour}

Despite marked differences between years in trip durations, foraging ranges and total distances travelled, the behaviour of birds during foraging trips was very similar each year. This agrees with previous findings from another study comparing 2 different gannet colonies (Hamer et al. 2001). In the present study, the average speed of travel over complete foraging trips was almost identical in all 3 years (Table 3 ) and the relationship between distance to destination and total distance travelled was also similar each year, as was the proportion of the total foraging area (95\% FKD) that comprised the core foraging area (Fig. 2). These data suggest that gannets did not alter their overall search strategy or sinuosity of foraging paths (i.e. the extent of deviation from a straight-line course) between years in relation to trip duration or foraging range.
In all 3 years studied, travel speed during daylight hours decreased significantly with increasing time intervals between locations (Eq. 4), presumably because travel speeds over longer intervals were more affected by deviations from a straight line course and by time that birds spent feeding and resting on the water (Ryan et al. 2004). Over the shortest intervals, where estimates were least affected by deviations from a straight line course, the mean travel speed was $32 \mathrm{~km} \mathrm{~h}^{-1}$ (from Eq. 4). This value is close to half the normal flight speed of gannets $\left(55 \mathrm{~km} \mathrm{~h}^{-1}\right.$; Grémillet et al. 2004), indicating that birds in all years spent roughly half their time at sea in flight. Garthe et al. (1999) and Lewis et al. (2004a) also found from external temperature loggers and activity loggers, respectively, that birds spent about half their time away from the colony in flight and the other half on the sea surface.

Hamer et al. (2001) recorded that gannets breeding at the Bass Rock foraged repeatedly over a narrow range of bearings before switching to a separate range of bearings in a markedly different direction from the colony, providing strong evidence that individuals learned and remembered the directions to feeding sites and used that knowledge on subsequent foraging trips. In contrast, birds at a much smaller colony (Great Saltee) in the Celtic Sea did not show this pattern (Hamer et al. 2001). This difference between colonies could have reflected differences in the spatial and temporal predictability of prey resources in the North Sea and Celtic Sea or differences in the costs and benefits of different foraging strategies in relation to travel time. Data from the present study indicate that birds at the Bass Rock foraged repeatedly over a narrow range of bearings in all 3 years despite marked annual variation in trip durations and foraging ranges (Table 2), supporting the notion that differences between colonies in the consistency of foraging locations are related mainly to differences in the spatial and temporal predictability of prey. Despite marked individual variation in the bearings of successive foraging trips, there was no variation among individuals in the durations or ranges of foraging trips, consistent with the notion that birds employed a form of network foraging (Clode 1993, Jaquemet et al. 2005) in which they set out on a bearing to a known feeding site and continued until they either located prey for themselves or encountered other birds flying towards a feeding flock Hamer et al. 2001).

\section{Constraints on foraging range}

In several species of seabirds, parents spend less time together at the nest between foraging trips in years with longer average trip durations (e.g. Mon- 
aghan et al. 1994, Litzow \& Piatt 2003). Gannets at the Bass Rock normally spend little time with their partners during chick rearing, and so long foraging trips can result in chicks being left unattended whilst both parents forage simultaneously (Lewis et al. 2004b). In this study, each adult was at the nest for about half the time in 2003 but for significantly less than that in the 2 years with longer average trip durations (Table 3), which strongly suggests that longer trips resulted in chicks being left unattended more often, as has also been observed in other species (e.g. great skuas Catharacta skua, Hamer et al. 1991; common guillemots Uria aalge, Wanless et al. 2005).

Unattended gannet chicks are frequently attacked and sometimes killed by conspecifics (Lewis et al. 2004 b), which is likely to result in a selective advantage to adults that return to the nest more quickly from distant foraging locations. In support of this notion, adults that attained greater distances from the colony returned significantly faster over distances up to ca. $300 \mathrm{~km}$ (Fig. 5), presumably returning by a more direct route and/or spending more time in flight and less time on the water resting and digesting prey. However the relationship contained a negative quadratic term, indicating that adults returned at slower average speeds from the furthest destinations (beyond ca. $400 \mathrm{~km}$ from the colony; Fig. 5). Moreover both maximum range and total distanced travelled at sea had an asymptotic relationship with trip duration, as also found for flight durations of black-legged kittiwakes Rissa tridactyla (Daunt et al. 2002), and these data provide further evidence of a constraint on the foraging ranges of gannets for trips longer than ca. $60 \mathrm{~h}$ (Figs. 3 \& 4). Gannets employ an energetically expensive mode of flight, and bioenergetics modelling indicated that whilst gannets at the Bass Rock had the capacity within their time/activity budgets to increase the proportion of time spent in flight during foraging trips, any such increase would probably exceed their maximal energetic capacity (Enstipp et al. 2006). The non-linear relationships observed in the present study, thus, probably reflected a constraint on the time that adults could spend in continuous flight back to the colony from distant foraging locations before exceeding their metabolic ceiling, and this constraint probably explains why there was no systematic increase in the proportion of time that birds spent in flight each year in relation to average trip duration.

Chicks were invariably fed at the end of foraging trips, and the results of this study indicate marked annual variation in feeding frequency. This may have been compensated for to some extent by variation in the sizes or caloric densities of meals delivered to chicks (as found by Lewis et al. 2003 in a comparison between gannet colonies). Thus, longer foraging trips need not necessarily have led to poor chick growth. However, long trips resulted in chicks being left unattended and vulnerable to attack, and adults were apparently constrained in their ability to reduce trip duration by returning more quickly from distant foraging locations. These data suggest that whilst adults have so far been able to maintain high reproductive success in years of low prey availability, they may not be able to do so in future years if providing sufficient food for chicks entails any further increases in trip duration or foraging effort.

Acknowledgements. We thank Sir H. Hamilton-Dalrymple for access to the Bass Rock, J. Croxall and B. Nelson for assistance in developing the project and B. Nelson and the Marr family for continuing logistic support and advice. We thank S. Lewis for invaluable assistance with dietary analysis and deployment of loggers, M. Carvalho for equally valuable help with kernel analysis and production of maps, and F. Daunt for assistance in obtaining sandeel data. This work was funded by grants from the European Union (Projects CEC 96-079 and Q5RS-200030864) and JNCC (Project F90-01-154).

\section{LITERATURE CITED}

Anonymous (1995) Review of sandeel biology. In: Report of the ICES workshop on sandeel otolith analysis. ICES CM 1995/9, p 4

Awkerman JA, Fukuda A, Higuchi H, Anderson DJ (2005) Foraging ecology and submesoscale habitat use of waved albatrosses Phoebastria irrorata during chick-brooding period. Mar Ecol Prog Ser 291:289-300

Beisiegel BM, Mantovani W (2006) Habitat use, home range and foraging preferences of the coati Nasua nasua in a pluvial tropical Atlantic forest area. J Zool Lond 269: $77-87$

Burnham KP, Anderson DR (1998) Model selection and inference. A practical information-theoretic approach. Springer, New York

Clode D (1993) Colonially breeding seabirds - predators or prey? Trends Ecol Evol 8:336-338

Croxall JP, Reid K, Prince PA (1999) Diet, provisioning and productivity responses of marine predators to differences in availability of Antarctic krill. Mar Ecol Prog Ser 177: 115-131

Daunt F, Benvenuti S, Harris MP, Dall'Antonia L, Elston D, Wanless S (2002) Foraging strategies of the black-legged kittiwake Rissa tridactyla at a North Sea colony: evidence for a maximum foraging range. Mar Ecol Prog Ser 245: 239-247

Enstipp MR, Daunt F, Wanless S, Humphreys EM, Hamer KC, Benvenuti S, Grémillet D (2006) Foraging energetics of North Sea birds confronted with fluctuating prey availability. In: Boyd I, Wanless S, Camphuysen CJ (eds) Top predators in marine ecosystems. Their role in monitoring and management. Cambridge University Press, Cambridge, p 191-210

Frederiksen M, Edwards M, Richardson AJ, Halliday NC, Wanless S (2006) From plankton to top predators: bottomup control of a marine food web across four trophic levels. J Anim Ecol 75:1259-1268

Garthe S, Grémillet D, Furness RW (1999) At-sea activity and foraging efficiency in chick-rearing northern gannets (Sula 
bassana): a case study in Shetland. Mar Ecol Prog Ser 185: 93-99

Garthe S, Benvenuti S, Montevecchi WA (2000) Pursuit plunging by northern gannets (Sula bassanus) feeding on capelin (Mallotus villosus). Proc R Soc Lond B Biol Sci 267: 1717-1722

Grémillet D, Dell'Omo G, Ryan PG, Peters G, Ropert-Coudert Y, Weeks SJ (2004) Offshore diplomacy or how seabirds mitigate intra-specific competition: a case study based on GPS tracking of Cape gannets from neighbouring colonies. Mar Ecol Prog Ser 268:265-279

Hamer KC, Furness RW, Caldow RWG (1991) The effects of changes in food supply on the breeding ecology of great skuas Catharacta skua in Shetland. J Zool (Lond) 223: 175-188

Hamer KC, Monaghan P, Uttley JD, Walton P, Burns MD (1993) The influence of food supply on the breeding ecology of kittiwakes Rissa tridactyla in Shetland. Ibis 135:255-263

Hamer KC, Phillips RA, Wanless S, Harris MP, Wood AG (2000) Foraging ranges, diets and feeding locations of gannets in the North Sea: evidence from satellite telemetry. Mar Ecol Prog Ser 200:257-264

Hamer KC, Phillips RA, Hill JK, Wanless S, Wood AG (2001) Contrasting foraging strategies of gannets Morus bassanus at two North Atlantic colonies: foraging trip duration and foraging area fidelity. Mar Ecol Prog Ser 224: 283-290

Hamer KC, Lewis S, Wanless S, Phillips RA, Sherratt TN, Humphreys EM, Hennicke J, Garthe S (2006) Using gannets to monitor marine ecosystems: colony size, prey patchiness and foraging area fidelity. In: Boyd I, Wanless $\mathrm{S}$, Camphuysen CJ (eds) Top predators in marine ecosystems. Their role in monitoring and management. Cambridge University Press, Cambridge, p 236-248

Härkönen T (1986) Guide to the otoliths of the bony fishes of the Northeast Atlantic. Danbiu ApS, Hellerup

Head A, Gales R (2005) Breeding and overwintering ecology of shy albatrosses in southern Australia: year-round patterns of colony attendance and foraging-trip durations. Condor 107:375-387

ICES (2005) Report of the ICES advisory committee on fisheries management, advisory committee on the marine environment and advisory committee on ecosystems, 2005. ICES Advice Vols 1-11, ICES, Copenhagen

Iversen SA, Esler D (2006) Site fidelity and the demographic implications of winter movements by a migratory bird, the harlequin duck Histrionicus histrionicus. J Avian Biol 37: 219-228

Jaquemet S, Le Corre M, Marsac F, Potier M, Weimerskirch H (2005) Foraging habitats of the seabird community of Europa Island (Mozambique Channel). PSZN I: Mar Ecol 147:573-582

Lewis S, Benvenuti S, Dall'Antonia L, Griffiths R, Money L, Sherratt TN, Wanless S, Hamer KC (2002) Sex-specific foraging behaviour in a monomorphic seabird. Proc $\mathrm{R}$ Soc Lond B Biol Sci 269:1687-1693

Lewis S, Sherratt TN, Hamer KC, Harris M, Wanless S (2003) Contrasting diet quality of northern gannets at two different colonies. Ardea 91:167-176
Lewis S, Benvenuti S, Daunt F, Wanless S and 5 others (2004a) Partitioning of diving effort in foraging trips of northern gannets. Can J Zool 82:1910-1916

Lewis S, Hamer KC, Money L, Redman KK, Griffiths R, Wanless S, Sherratt TN (2004b) Brood neglect and contingent foraging behaviour in a pelagic seabird. Behav Ecol Sociobiol 56:81-88

Lewis S, Schreiber EA, Daunt F, Schenk GA, Orr K, Adams E, Wanless S, Hamer KC (2005) Sex-specific foraging behaviour in tropical boobies: Does size matter? Ibis 147:408-414

Litzow MA, Piatt JF (2003) Variance in prey abundance influences time budgets of breeding seabirds: evidence from pigeon guillemots Cepphus grille. J Avian Biol 34:54-64

Mavor RA, Parsons M, Heubeck M, Schmitt S (2004) Seabird numbers and breeding success in Britain and Ireland, 2003. Joint Nature Conservation Committee (UK Nature Conservation, No. 28), Peterborough

Mavor RA, Parsons M, Heubeck M, Schmitt S (2005) Seabird numbers and breeding success in Britain and Ireland, 2004. Joint Nature Conservation Committee (UK Nature Conservation, No. 29), Peterborough

Monaghan P, Walton P, Wanless S, Uttley JD, Burns MD (1994) Effects of prey abundance on the foraging behaviour, diving efficiency and time allocation of breeding guillemots Uria aalge. Ibis 136:214-222

Nelson B (2006) Mean laying dates in the northern gannet. Scott Birds 26:50

Phillips RA, Xavier JC, Croxall JP (2003) Effects of satellite transmitters on albatrosses and petrels. Auk 120:1082-1090

Ropert-Coudert YR, Grémillet D, Kato A, Ryan PG, Naito Y, Le Maho Y (2004) A fine-scale time budget of Cape gannets provides insights into the foraging strategies of coastal seabirds. Anim Behav 67:985-992

Ryan PG, Petersen SL, Peters G, Grémillet D (2004) GPS tracking a marine predator: the effects of precision, resolution and sampling rate on foraging tracks of African penguins. Mar Biol 145:215-223

Thompson KR, Pickerell G, Heubeck M (1999) Seabird numbers and breeding success in Britain and Ireland, 1998. Joint Nature Conservation Committee (UK Nature Conservation, No. 23), Peterborough

Wanless S, Wright PJ, Harris MP, Elston DA (2004) Evidence for decrease in size of lesser sandeels Ammodytes marinus in a North Sea aggregation over a 30 -yr period. Mar Ecol Prog Ser 279:237-246

Wanless S, Harris MP, Redman P, Speakman JR (2005) Low energy values of fish as a probable cause of a major seabird breeding failure in the North Sea. Mar Ecol Prog Ser 294: $1-8$

Watt J, Pierce GJ, Boyle PR (1997) Guide to the identification of North Sea fish using premaxillae and vertebrae. ICES Coop Res Rep No 220. ICES, Copenhagen, p 1-231

Weimerskirch H, Le Corre M, Ropert-Coudert Y, Kato A, Marsac F (2006) Sex-specific foraging behaviour in a seabird with reversed sexual dimorphism: the red-footed booby. Oecologia 146:681-691

Wilson RP, Scolaro JA, Grémillet D, Kierspel MAM and 8 others (2005) How do magellanic penguins cope with variability in their access to prey? Ecol Monogr 75:379-401

Submitted: July 24, 2006; Accepted: October 17, 2006

Proofs received from author(s): May 2, 2007
Editorial responsibility: Otto Kinne (Editor-in-Chief), Oldendorf/Luhe, Germany 